\title{
HAF, Hepatoma Aggregation Factor Produced by Streptomyces sp. Strain No. A-6143
}

\author{
Keitarou Suzuki, Nahoko Nakano, Yuko Nagatomi, \\ Hideyuki Tominaga, Naoko Nakazono, Mieko ITAI, \\ Masaru Uyeda and Motoo Shibata \\ Laboratory of Medicinal Microbiology, Faculty of Pharmaceutical Sciences, \\ Kumamoto University, Kumamoto 862, Japan
}

Received February 23, 1990

\begin{abstract}
We searched for a new cell aggregation factor for hepatoma AH109A cells, and found one we called HAF in the culture filtrate of Streptomyces sp. strain No. A-6143 isolated from a soil sample. HAF was purified by salting-out with ammonium sulfate, DEAE-cellulose column chromatography, gel filtration on Sephadex G-100, and hydroxylapatite column chromatography. HAF was a glycoprotein which had a molecular weight of about 73,000 . $\mathrm{HAF}$ was stable from $\mathrm{pH} 6$ to 8 at $37^{\circ} \mathrm{C}$ and up to $40^{\circ} \mathrm{C}$ at $\mathrm{pH} \mathrm{8.0,} \mathrm{and} \mathrm{the} \mathrm{aggregation} \mathrm{activity} \mathrm{of} \mathrm{HAF} \mathrm{was} \mathrm{maximum} \mathrm{around} \mathrm{pH} 8$ at $30^{\circ} \mathrm{C}$. The activity was not influenced by some saccharides, but it was inhibited by EDTA and EGTA; moreover HAF activity was restored by the addition of calcium ions. HAF aggregated hepatoma AH136B and COS-7 cells as well as hepatoma AH109A cells, but it was inert to other cancer cells and human erythrocytes. These properties proved that HAF is completely different from other aggregation factors for cancer cells so far reported.
\end{abstract}

Intracellular adhesion is of fundamental importance in the physiology of multicellular organisms. Several attempts to clarify the mechanism of intracellular adhesion have proved that it is a highly complex phenomenon in which many factors operate, i.e., adhesive substances, divalent cations, and so on.

Extracellular factors having cell adhesion activity have been obtained from normal and malignant cells. ${ }^{1-4)}$ Moreover, a number of cell aggregation substances are obtained from various microorganisms. Among them, some factors, ${ }^{5-9)}$ such as mouse tumor cell agglutinin ${ }^{6)}$ and canacelunin ${ }^{7)}$ which aggregate cancer cells, are produced by streptomycetes, and do not aggregate erythrocytes. And also, we reported that SAF, ${ }^{10,11)} 3315-\mathrm{AF}^{12)}$ and 3315 $\mathrm{AF} 2^{13)}$ produced by streptomycetes did not aggregate erythrocytes, and that these factors aggregated microorganisms and cancer cells differentially.

To obtain a new factor aggregating hepatoma AH109A cells, we screened various microorganisms, and a factor was found in the culture filtrate of Streptomyces sp. strain No. A-6143, which was isolated from a soil sample. By comparing biochemical and physicochemical characteristics of the factor with those of other known aggregation substances, we found that this is a new aggregation factor. Hereafter, this factor will be referred to as HAF. In this paper, the purification procedure and some properties of HAF are described.

\section{Materials and Methods}

Organisms and materials. Hepatoma AH109 $\mathrm{A}^{14)}$ cells have been maintained in our laboratory by routine 6-dayinterval passage of $2 \times 10^{6}$ cells inoculated intraperitoneally into $70-90 \mathrm{~g}$ male rats of the Donryu strain. Leukemia P388 cells (mouse DBA, i.p., 5 days culture), sarcoma 180 cells (mouse ddY, i.p., 7 days culture) and hepatoma AH136B (Donryu rat, i.p., 10 days culture) are all cells maintained in our laboratory. After removal of cells from the animals by injector, each cell type except for hepatoma AH136B forming cell islands in vivo was washed several times with Hanks' balanced salt solution (HBSS). To obtain dissociated cells of hepatoma AH136B, AH $136 \mathrm{~B}$ cells were suspended in $\mathrm{Ca}, \mathrm{Mg}$-free $\mathrm{HBSS}$, and trypsin was added to the suspension to a final concen- 
tration of $25 \mathrm{mg} / \mathrm{ml}$, followed by shaking at $37^{\circ} \mathrm{C}$ for $15 \mathrm{~min}$. The cells suspended in Rabinowitz' balanced salt solution containing $0.45 \mathrm{~mm}$ EDTA were dissociated by gentle pipetting for $15 \mathrm{~min}$ at $37^{\circ} \mathrm{C}$ and eluted on a nylon wool column. The dissociated cells of hepatoma AH136B thus obtained were washed with $\mathrm{Ca}, \mathrm{Mg}$-free HBSS.

Neutrophils, eosinophils, and macrophages of guinea pig, and lymphocytes and L-cells of mouse were kindly provided by Dr. Tominaga of the College of Medicinal Sciences, Kumamoto University. Human cells such as HL60 , U-937, and THP-1 were purchased. Human erythrocytes were prepared from commercially obtained blood. The reagents used were guaranteed grades commercially available.

Screening test for microorganisms that produced aggregation factor. The strains of Streptomyces sp. isolated from soils were inoculated in S medium consisting of $2 \%$ glucose, $3 \%$ starch, $1 \%$ corn steep liquor, $1 \%$ soybean flour, $0.5 \%$ peptone, $0.3 \% \mathrm{NaCl}$, and $0.5 \% \mathrm{CaCO}_{3}(\mathrm{pH} 7.0$ ), and cultivated at $28^{\circ} \mathrm{C}$ for 3 to 5 days on a rotary shaker ( $180 \mathrm{rpm}, 5 \mathrm{~cm}$ radius). After cultivation, the mycelia were removed by centrifugation and the culture filltrates were assayed for aggregation activity by the microtiter method using cell suspension of hepatoma AH109A.

Assay of aggregation activity. Aggregation activity was observed directly with a light microscope. The cell suspension was diluted with HBSS to obtain a cell count of $1 \times 10^{7}$ cells $/ \mathrm{ml}$. Forty $\mu$ of a serial dilution of aggregation factor in HBSS was prepared in flat wells of a microtiter plate. Then $10 \mu$ of the above cell suspension was added to each well and mixed well. The mixture was left to stand for $60 \mathrm{~min}$ at $28^{\circ} \mathrm{C}$ and then $250 \mu$ l of HBSS was added to each mixture. The mixture was examined with a microscope for the occurrence of aggregation relative to the control con- taining no factor. The activity was expressed as the reciprocal of concentration of aggregation factor with positive aggregation.

Disc electrophoresis. Polyacrylamide gel disc electrophoresis was done by the method of Davis ${ }^{15)}$ at $\mathrm{pH} 8.0$. A sample was put on the top of the stacking gel $(7.5 \%$ acrylamide) and run at the constant current of $3 \mathrm{~mA}$ per gel column for $60 \mathrm{~min}$ at $5^{\circ} \mathrm{C}$. After electrophoresis, the gel was stained with $0.2 \%$ Coomassie brilliant blue R-250 in methanol-acetic acid-water $(5: 1: 5, \mathrm{v} / \mathrm{v})$, and destained with $7.5 \%$ acetic acid in $5 \%$ methanol. Fuchsin-sulfite staining of the gels was done using the periodic acidSchiff's base technique of Zacharius et al., ${ }^{16)}$ which was originally used for the detection of glycoprotein after gel electrophoresis.

\section{Results and Discussion}

\section{Results of screening}

Culture filtrates of streptomycetes were tested by assay method described in Materials and Methods. Among 200 strains of streptomycetes tested, 11 strains produced a kind of aggregation factor toward hepatoma AH109A cells in their culture filtrates. Nine strains among them also aggregated human erythrocytes. Only two strains aggregated hepatoma AH109A cells without aggregating erythrocytes. The strain No. A-6143 had higher aggregation activity than another one, and the activity was not observed in the mycelia of this strain. Therefore, further studies were

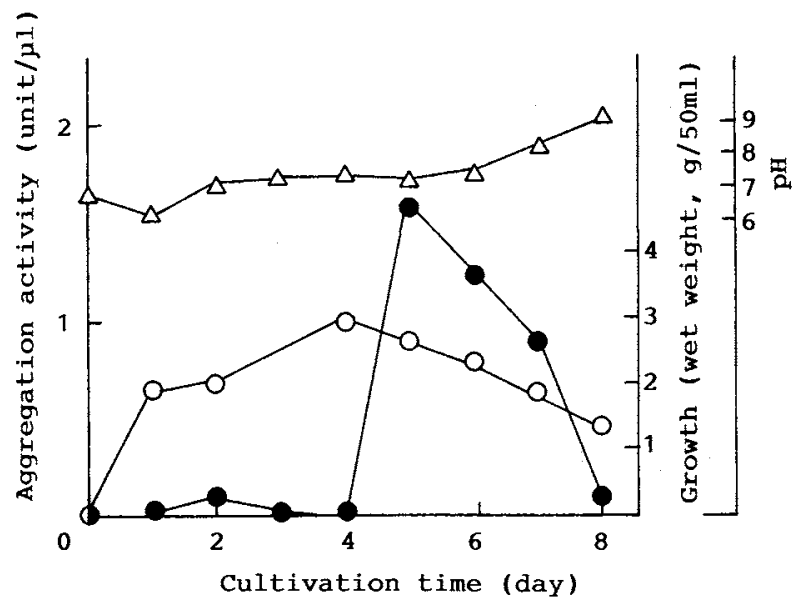

Fig. 1. Changes in Strain No. A-6143 Culture.

-, aggregation activity (unit $/ \mu 1$ ); $\bigcirc$, growth; $\triangle, \mathrm{pH}$. 
made using Streptomyces sp. strain No. A6143.

\section{Conditions for producing aggregation factor by} the strain No. A-6143 culture

The culture conditions were examined to obtain the highest production of aggregation factor, and optimal conditions are summarized in Table I. Under these culture conditions, changes in aggregation activity and $\mathrm{pH}$ in the culture filtrate, and growth of mycelia with cultivation time are shown in Fig. 1. Aggregation activity appeared in its death phase. The activity reached a maximum at 5 days of cultivation, and thereafter its activity gradually decreased as the mycelia began to decrease and the $\mathrm{pH}$ rose. The factor in the

Table I. Culture Conditions for the Production OF HAF

$\begin{array}{lll}\text { Strain used } & : \text { Streptomyces sp. strain No. A-6143 } \\ \text { Culture medium } & \text { S medium } \\ \text { Initial pH } & : & 7.0 \\ \text { Culture temp. } & : & 28^{\circ} \mathrm{C} \\ \text { Culture volume } & : & 50 \mathrm{ml} \text { medium } / 200 \mathrm{ml} \text { flask } \\ \text { Agitation } & : & 180 \mathrm{rpm} \\ \text { Seed culture } & : & 2 \text { days } \\ \text { Main culture } & : & 5 \text { days }(4 \% \text { seed })\end{array}$

culture filtrate which aggregates hepatoma AH109A cells was designated as HAF, as described in the introduction.

\section{Production and purification of $H A F$}

Strain No. A-6143 was cultivated for 5 days, and the mycelia were removed by centrifugation at $10,000 \times g$ for $20 \mathrm{~min}$. HAF required calcium ions for its activity and stability, so we were careful to maintain the calcium ion concentration in all purification procedures.

At first, to the clear supernatant was added solid ammonium sulfate to give $80 \%$ saturation. After standing overnight at $5^{\circ} \mathrm{C}$, the precipitate was collected by centrifugation, dissolved in a minimal volume of $0.02 \mathrm{M}$ Tris $-\mathrm{HCl}(\mathrm{pH} 8.0)$ containing $5 \mathrm{~mm} \mathrm{CaCl}_{2}$ and then dialyzed against the same buffer for 2 days to free it from ammonium sulfate. This dialysate was put on a DEAE-cellulose column $(2.7 \times 30 \mathrm{~cm})$ that had been equilibrated with the above buffer. HAF was eluted with the same buffer containing a linear concentration gradient of $\mathrm{NaCl}$ from 0 to $0.5 \mathrm{M}$. The active fractions (tubes 45-55, active fraction I) were combined and two volumes of cold ethanol were added to the solution. The pre-

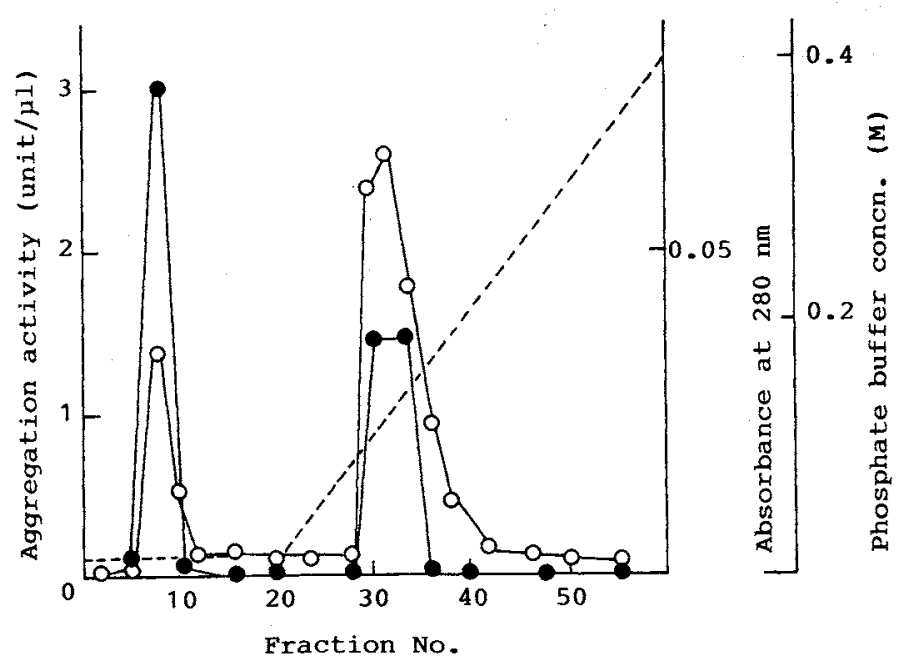

Fig. 2. Column Chromatography of HAF on Hydroxylapatite.

Column size, $1.8 \times 13 \mathrm{~cm}$; fraction size, $5 \mathrm{ml}$; flow rate, $10 \mathrm{ml} / \mathrm{hr}$; eluant, phosphate buffer $(\mathrm{pH} 7.0)$ of linear concentration from $0.01 \mathrm{M}$ to $0.4 \mathrm{M}$. - aggregation activity (unit $/ \mu \mathrm{l}$ ); $\bigcirc$, absorbance at $280 \mathrm{~nm} ;-\ldots$, concentration of phosphate buffer (M). 
cipitate was collected by centrifugation and dissolved in a minimal volume of $0.02 \mathrm{M}$ Tris$\mathrm{HCl}(\mathrm{pH} 8.0$ ) containing $0.1 \mathrm{M} \mathrm{NaCl}$ and $5 \mathrm{mM} \mathrm{CaCl}_{2}$, and then dialyzed against the same buffer at $4^{\circ} \mathrm{C}$. The dialysate thus obtained was put on a Sephadex G-100 column $(1.5 \times 76 \mathrm{~cm})$, and eluted with the above dialysing buffer. The active fractions (tubes 3645 , active fraction II) were combined and two volumes of cold ethanol were added. The resulting precipitate was dissolved in $0.01 \mathrm{M}$ phosphate buffer ( $\mathrm{pH} \mathrm{7.0)}$ and then dialyzed against the same buffer at $4^{\circ} \mathrm{C}$. The dialysate was put on a hydroxylapatite column $(1.8 \times$ $13 \mathrm{~cm}$ ) previously equilibrated with the same buffer. HAF was eluted with a linear gradient of the phosphate buffer $(10-400 \mathrm{~mm})$. The elution pattern is shown in Fig. 2. Two peaks of protein (OD at $280 \mathrm{~nm}$ ) appeared, and the aggregation activity was detected in both fractions. From the result of polyacrylamide gel electrophoresis, the second peak eluted with $0.15 \mathrm{M}$ phosphate buffer was contami-

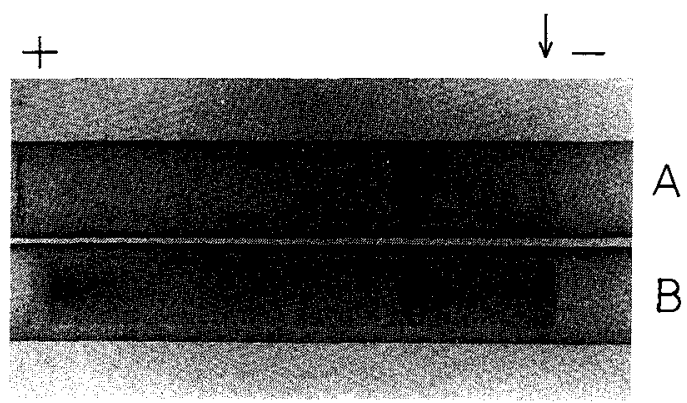

Fig. 3. Polyacrylamide Gel Disc Electrophoresis of HAF.

The arrow indicates the position of the sample. A: Gel stained with Coomassie brilliant blue R-250. B: Gel stained with periodic acid-Schiff's base. nated with some proteins having no aggregation activity, but the first peak that passed through the column was shown as a single band in the gel. Therefore, the active fraction (tubes 5-9) were combined and dialyzed against water to remove any salt and then lyophilized.

Homogeneity of HAF was examined by polyacrylamide gel disc electrophoresis at $\mathrm{pH}$ 8.0. As shown in Fig. 3, HAF gave a single, clear band in the gel stained with Coomassie brilliant blue R-250 or periodic acid-Schiff's base, so HAF was regarded as a homogeneous glycoproein.

Table II shows a summary of purification of HAF from the culture filtrate. The factor was purified 1990 times on the basis of protein (unit/OD at $280 \mathrm{~nm}$ ) with a yield of $26 \%$ from the culture filtrate. Finally, about $800 \mu \mathrm{g}$ of HAF was obtained from $710 \mathrm{ml}$ of the culture filtrate, and $1.4 \times 10^{-3} \mu \mathrm{g}$ of HAF gave 1 unit

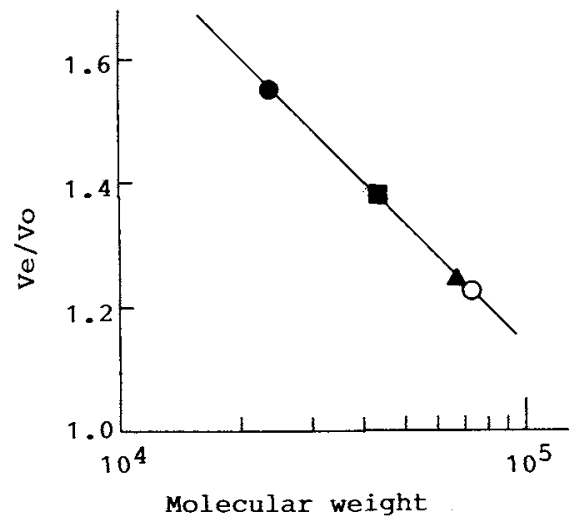

Fig. 4. Molecular Weight Measurement of HAF on Sephadex G-100 Column.

O, trypsin (MW: 24,000); $\mathbf{\square}$, ovalbumin (MW: 46,000);

$\Delta$, bovine serum albumin (MW: 67,000); O, HAF.

Table II. Summary of Purification Steps of HaF

\begin{tabular}{lcccrr}
\hline Purification step & $\begin{array}{c}\text { Volume } \\
(\mathrm{ml})\end{array}$ & $\begin{array}{c}\text { Total activity } \\
\left(\text { unit } \times 10^{-3}\right)\end{array}$ & $\begin{array}{c}\text { Yield } \\
(\%)\end{array}$ & $\begin{array}{c}\text { Specific activity } \\
\text { (unit/OD } 280\end{array}$ & $\begin{array}{c}\text { Purification } \\
\text { rate }\end{array}$ \\
\hline Culture filtrate & 710 & 2,272 & 100 & 215 & 1 \\
Active fraction 1 & 114 & 1,459 & 64 & 10,490 & 48 \\
Active fraction II & 35 & 224 & 10 & 20,000 & 93 \\
Dialysate & 7 & 364 & 16 & 40,950 & 190 \\
Purified HAF & 23 & 591 & 26 & 428,300 & 1,990 \\
\hline
\end{tabular}


in the assay system as described in Materials and Methods.

\section{Ultraviolet absorption spectrum of $H A F$}

Lyophilized HAF was dissolved in deionized water $(1 \mathrm{mg} / \mathrm{ml})$ for ultraviolet absorption measurement, and recorded on a Hitachi U-2000 spectrophotometer. The spectrum of HAF showed a maximum at $278 \mathrm{~nm}$ and minimum at $245 \mathrm{~nm}$. The spectrum was analogous to typical absorption spectra of proteins, indicating the presence of tyrosine and tryptophan in the HAF molecule. A $1 \%$ solution of HAF had an absorbance of 16.7 at $280 \mathrm{~nm}$.

\section{Molecular weight measurement of $H A F$}

The molecular weight of HAF was mea- sured by the method of Andrews ${ }^{17)}$ with a Sephadex G- 100 column at $5^{\circ} \mathrm{C}$ in $0.02 \mathrm{M}$ Tris$\mathrm{HCl}$ buffer $(\mathrm{pH} 8.0)$ containing $0.1 \mathrm{M} \mathrm{NaCl}$ and $5 \mathrm{~mm} \mathrm{CaCl}_{2}$. In Fig. 4, the ratio of elution volume to void volume was plotted against the logarithm of molecular weight for each reference protein. From the result, an approximate molecular weight of 73,000 was obtained for HAF.

Effects of $p H$ and temperature on the aggregation activity of $H A F$

The aggregation activity was measured while changing the $\mathrm{pH}$ from 3 to 11.0 . As shown in Fig. 5(A), the activity of HAF turned out to be pH-dependent. HAF showed weak aggregation activity at acidic $\mathrm{pH}$, the activity increased as the $\mathrm{pH}$ rose, and the activity was
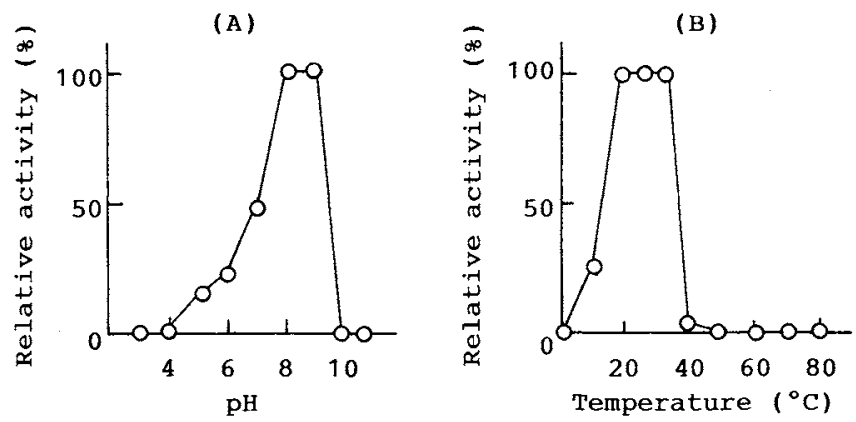

Fig. 5. Effects of $\mathrm{pH}$ and Temperature on the Aggregation Activity of HAF.

(A): The effects of $\mathrm{pH}$ on the activity were assayed at each $\mathrm{pH}$ at $28^{\circ} \mathrm{C}$ for $60 \mathrm{~min}$. The activity at $\mathrm{pH} 8.0$ was expressed as 100. (B): The effects of temperature on the activity were assayed at each temperature at $\mathrm{pH} 8.0$ for $60 \mathrm{~min}$. The activity at $28^{\circ} \mathrm{C}$ was expressed as 100 .
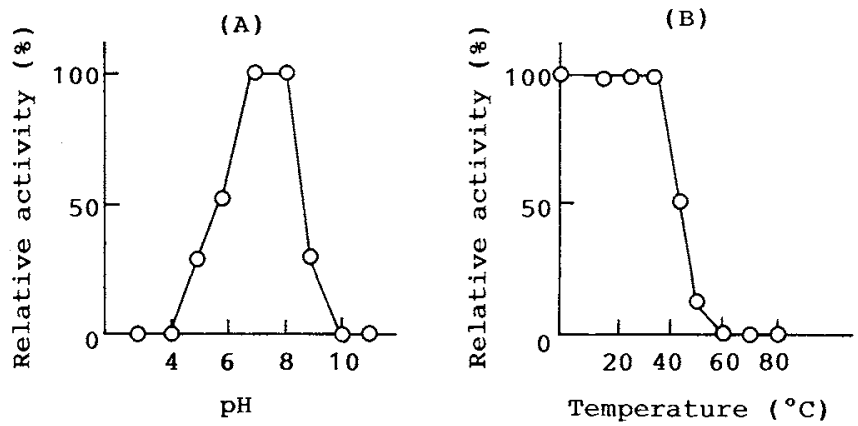

Fig. 6. Effects of $\mathrm{pH}$ and Temperature on the Stability of HAF.

(A): After incubation at each $\mathrm{pH}$ at $37^{\circ} \mathrm{C}$ for $60 \mathrm{~min}$, remaining activity was measured at $\mathrm{pH} 8.0$. Relative activity was expressed at $\mathrm{pH} 8.0$ as 100 . (B): After incubation at each temperature at $\mathrm{pH} 8.0$ for $60 \mathrm{~min}$, remaining activity was measured at $28^{\circ} \mathrm{C}$. Relative activity was expressed at $28^{\circ} \mathrm{C}$ as 100 . 
not shown at $\mathrm{pH}$ above 10 . The optimal $\mathrm{pH}$ of $\mathrm{HAF}$ for aggregation toward hepatoma AH109A cells was 8 to 9 .

The aggregation activity was examined at incubation temperatures from $0^{\circ} \mathrm{C}$ to $80^{\circ} \mathrm{C}$. Figure 5(B) shows that the activity was temperature-dependent as with $\mathrm{pH}$, and its activity was maximum at around $30^{\circ} \mathrm{C}$.

\section{Effects of $p H$ and temperature on stability of $H A F$}

The stability of HAF was tested in buffer solution of various $\mathrm{pHs}$ at $37^{\circ} \mathrm{C}$ for $60 \mathrm{~min}$. Residual activity was measured at $\mathrm{pH}$ 8.0. As shown in Fig. 6(A), HAF was stable from $\mathrm{pH} 7$ to 8 , but its activity was about $50 \%$ of the initial activity.

After treatment at various temperatures for $60 \mathrm{~min}$ at $\mathrm{pH} 8.0$, each remaining activity was assayed at $37^{\circ} \mathrm{C}$. As shown in Fig. 6(B), HAF was stable up to $40^{\circ} \mathrm{C}$, but gradual inactivation occurred above $40^{\circ} \mathrm{C}$, and $\mathrm{HAF}$ was completely inactivated at $60^{\circ} \mathrm{C}$.

\section{Effects of various reagents on the aggregation activity of $H A F$}

It is known that the productivity of $\mathrm{L}$ fucose- or D-mannose-specific lectins was widely distributed in streptomycetes. ${ }^{18,19)}$ And also, we reported that the aggregation activities of $\mathrm{SAF}^{10.11)}$ and $3315-\mathrm{AF}^{12)}$ were not inhibited by various saccharides, but both factors were inhibited by bovine serum albumin. The effects of various reagents on HAF activity were investigated by measuring the remaining aggregation activity toward hepatoma AH109A cells after incubation of $\mathrm{HAF}$ with each reagent at $\mathrm{pH} 8.0$ and $37^{\circ} \mathrm{C}$ for $10 \mathrm{~min}$. As shown in Table III, HAF was not affected by any saccharide or bovine serum albumin, but HAF was strongly inhibited by ethylenediaminetetraacetic acid (EDTA) and ethylene glycol $\operatorname{bis}(\beta$-aminoethylether)$N, N, N^{\prime}, N^{\prime}$-tetraacetic acid (EGTA).

Oishi et al. ${ }^{6)}$ reported that the aggregation at $\mathrm{pH} 6$ of mouse tumor cell agglutinin from streptomycetes was strongly inhibited by EDTA and the inhibition was not restored by
Table III. EFFEcts of VARIOUS REAGENTS ON THE AgGregation ACTIVITY OF HAF

\begin{tabular}{lcc}
\hline \multicolumn{1}{c}{ Reagent } & $\begin{array}{c}\text { Concentration } \\
(\mathrm{mM})\end{array}$ & $\begin{array}{c}\text { Aggregation } \\
\text { activity }(\%)\end{array}$ \\
\hline D-Fucose & 10 & 100 \\
L-Fucose & 10 & 100 \\
D-Galactose & 10 & 100 \\
D-Glucose & 10 & 100 \\
D-Mannose & 10 & 100 \\
$N$-Acetylgalactosamine & 10 & 100 \\
$N$-Acetylglucosamine & 10 & 100 \\
Lactose & 10 & 100 \\
Hyaluronic acid & $100 \mu \mathrm{g}^{b}$ & 100 \\
Bovine serum albumin & $100 \mu \mathrm{g}$ & 100 \\
Ovalbumin & $100 \mu \mathrm{g}$ & 100 \\
EDTA & 10 & 0 \\
EGTA & 10 & 0
\end{tabular}

a The activity of HAF was measured with each reagent in the standard assay solution $(50 \mu \mathrm{l})$, and the activity without each reagent was expressed as 100 .

$b$ Each $100 \mu \mathrm{g}$ /incubation mixture.

Table IV. Reactivation of EDTA-Treated HAF WITH CALCIUM IONS

The activity was shown as a relative value to that obtained from the buffer without EDTA.

\begin{tabular}{lcc}
\hline & With EDTA & Without EDTA \\
\hline $\mathrm{CaCl}_{2}$ not added & 0 & 100 \\
$\mathrm{CaCl}_{2}$ added & 100 & 100 \\
\hline
\end{tabular}

the addition of a sufficient amount of calcium and/or magnesium ions. Therefore, reactivation of EDTA-treated HAF with calcium ions was examined. After HAF was incubated with final $1 \mathrm{~mm}$ EDTA at $0^{\circ} \mathrm{C}$ for $10 \mathrm{~min}$, $\mathrm{CaCl}_{2}$ solution was added to make a final concentration of $1 \mathrm{~mm}$ in the mixture, and then the aggregation activity was assayed using $\mathrm{Ca}$, Mg-free HBSS. As shown in Table IV, HAF completely lost its activity by incubation with EDTA, however this EDTA-inhibition disappeared upon the addition of calcium ions, thus differing from mouse tumor cell agglutinin. The fact also suggested that calcium atoms, which were essential for its activity, might be contained in the HAF molecule. 


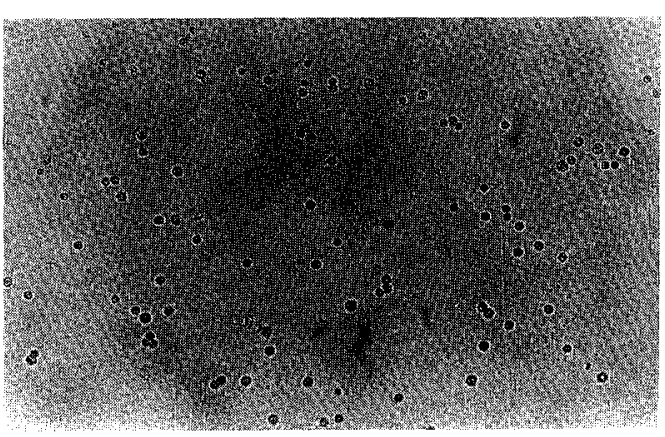

Before treatment with HAF

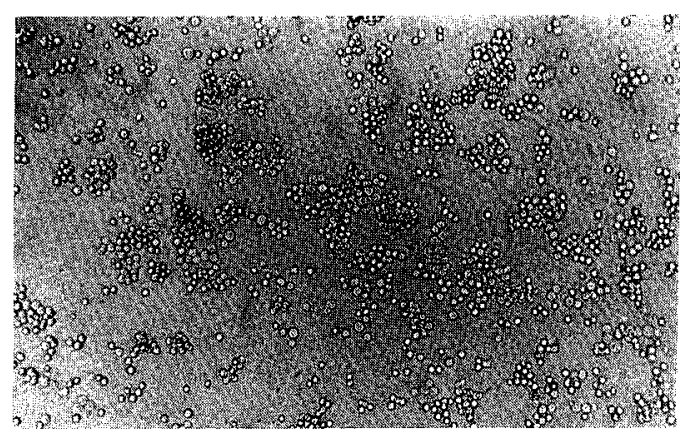

After treatment with $\mathrm{HAF}$

Fig. 7. Hepatoma AH109A Cells before and after Treatment with HAF.

Table V. Effects of HAF on Various Animal Cells

\begin{tabular}{llc}
\hline \multicolumn{1}{c}{ Animal cell } & & $\begin{array}{c}\text { Amount required to } \\
\text { cause aggregation } \\
(\mathrm{ng} / \mathrm{ml} \text { of inc. mix.) }\end{array}$ \\
\hline Hepatoma AH109A (rat) & 28 \\
Hepatoma AH136B (rat) & (monkey) & 28 \\
COS-7 & (mouse) & $>7000$ \\
L-Cell & (mouse) & $>7000$ \\
Leukemia P388 & (human) & $>7000$ \\
HL-60 & (human) & $>7000$ \\
U-937 & (human) & $>7000$ \\
THP-1 & (human) & \\
HeLa & & $>7000$ \\
Erythrocyte & (human; A, B, O, AB-type) & $>7000$ \\
Lymphocyte & (mouse) & $>7000$ \\
Macrophage & (guinea pig) & $>7000$ \\
Neutrophil & (guinea pig) & (guinea pig) \\
Eosinophil & & $>7000$ \\
\hline
\end{tabular}

a The aggregation was observed directly by microscope as described in the text.

\section{Effects of HAF on various animal cells}

The aggregation activity of HAF was tested toward various animal cells. The results of Table $\mathrm{V}$ shows the minimal amount of HAF causing cell aggregation. The dissociated cells of hepatoma AH136B and COS-7 cells were aggregated by HAF and the concentration of HAF causing aggregation was similar to that toward hepatoma AH109A cells, but HAF did not aggregate the other tumor cells, erythrocytes, and so on. Figure 7 shows hepatoma AH109A cells before and after treatment with HAF. HAF had rather high selectivity toward a kind of cancer cells. While a change of cellsurface by HAF is not proven, this differential aggregation indicated that some specific interaction between the surface of the cells and HAF must be involved in the aggregation.

Numerous microorganisms produce cell aggregation substances which do nọt aggregate human erythrocytes. Among them, SAF, ${ }^{10-11)}$ $3315 \mathrm{AF},{ }^{12)}$ mouse tumor cell agglutinin, ${ }^{6)}$ and canacelunin,${ }^{77}$ which aggregate cancer cells are produced by Streptomyces sp. as is HAF. HAF is distinguished from these four factors in the cell-specificity of aggregation activity. Wheat germ agglutinin from Triticum vulgaris aggregates hepatoma AH109A, but this lectin also aggregates human erythrocytes. ${ }^{20)} \mathrm{Cal}-$ cium ions are concerned with the aggregation activity of HAF. Sponge aggregation factor $^{11}$ and cadherins ${ }^{2)}$ from animal cells require calcium ions for their activities. HAF was also distinguished from these factors by other properties. HAF was similar in its molecular weight and selectivity toward cancer cells to cell surface-associated adhesive factor, ${ }^{3)}$ which is a glycoprotein, from rat hepatoma AH136B cells. However, HAF differs from this factor since the aggregation activity of this factor is inhibited by D-mannose. Thus, all data reported above suggested that HAF is a new aggregation factor that aggregates cancer cells.

HAF has high selectivity toward hepatoma AH109A cells. It would be interesting to find the HAF binding site on the cell surface. The 
receptor for HAF and the mode of action are now under investigation, and the results will be described in our next paper.

\section{References}

1) P. Henkart, S. Humphreys and T. Humphreys, Biochemistry, 12, 3045 (1973).

2) Y. Shirayoshi, T.S. Okada and M. Takeichi, Cell, 35, 631 (1983).

3) S. Kurano, M. Ishida and Y. Ishimaru, J. Cell Science, 66, 367 (1984).

4) S. Benchimol, A. Fuks, S. Jothy, N. Beauchemin, K. Shirota and C. P. Stanners, Cell, 57, 327 (1989).

5) M. Crandall and T. D. Brock, Bacteriol. Review, 32, 139 (1968).

6) K. Oishi and K. Aida, Agric. Biol. chem., 39, 183 (1975).

7) T. Ikekawa, T. Asari, T. Manabe, M. Umeji, S. Yanoma and K. Oishi, J. Antibiot, 33, 776 (1980).

8) K. Sakka, T. Endo, M. Watanabe, S. Okuda and H. Takahashi, Agric. Biol. Chem., 45, 497 (1981).
9) K. Kodama and M. Murata, Agric. Biol. Chem., 48, 2423 (1984).

10) K. Suzuki, M. Kosai, K. Yokomizo, M. Uyeda and M. Shibata, Agric. Biol. Chem., 51, 3017 (1987).

11) K. Suzuki, M. Kosai, K. Yokomizo, M. Uyeda and M. Shibata, Agric. Biol. Chem., 52, 555 (1988).

12) K. Suzuki, N. Nakano, R. Tanaka, M. Uyeda and M. Shibata, Agric. Biol. Chem., 52, 2589 (1988).

13) M. Uyeda, K. Suzuki and M. Shibata, Agric. Biol. Chem., 54, 251 (1990).

14) S. Odashima, J. Natn. cancer Inst. Monog., 16, 51 (1964).

15) B. J. Davis, Ann. N. Y. Acad. Sci., 121, 404 (1964).

16) R. M. Zacharius, T. E. Zell, T. H. Morrison and J. J. Woodlock, Anal. Biochem., 30, 148 (1969).

17) P. Andrews, Biochem. J., 96, 595 (1965).

18) T. Kameyama, K. Oishi and K. Aida, Biochim. Biophys. Acta, 587, 407 (1979).

19) I. Matsui, K. Oishi, K. Kanaya and N. Baba, $J$. Biochem., 97, 399 (1985).

20) D. F. Smith, G. Neri and E. F. Walborg, Biochemistry, 12, 2111 (1973). 